\title{
SATELLITE-MEASURED SPATIAL AND TEMPORAL CHLOROPHYLL- $A$ VARIABILITY IN THE GULF OF TOMINI, SULAWESI
}

\author{
I Nyoman Radiarta \# \\ Research Center for Aquaculture, Agency for Marine and Fisheries Research
}

\begin{abstract}
Chlorophyll-a concentration, an index of phytoplankton biomass, is an important parameter for fisheries resources and marine aquaculture development. Spatial and temporal variability of surface cholophyll- $a(\mathrm{chl}-a)$ concentration and water condition in the Gulf of Tomini were investigated using monthly climatologies the Sea-viewing Wide Field-of-view sensor (SeaWiFS), sea surface temperature (SST), and wind data from January 2000 to December 2007. The results showed seasonal variation of chl$a$ and SST in the Gulf of Tomini. High chl- $a$ concentrations located in the eastern part of the gulf were observed during the southeast monsoon in August. During the northwest monsoon, chl- $a$ concentrations were relatively low $\left(<0.2 \mathrm{mg} \mathrm{m}^{-3}\right)$ and distributed uniformly throughout most of the region. Chl- $a$ concentrations peaked in August at every year, and chl-a concentrations were observed low in November at every year from 2000 to 2007 . SSTs were relatively high $\left(>28^{\circ} \mathrm{C}\right)$ during the northwest monsoon, but low during the southeast monsoon. High wind speed was coincided with high chl-a concentrations. Local forcing such as sea surface heating and wind condition are the mechanisms that controlled the spatial and temporal variations of chlorophyll concentrations.
\end{abstract}

KEYWORDS: chlorophyll-a, SeaWiFS, sea surface temperature, wind, Gulf of Tomini, Sulawesi

\section{INTRODUCTION}

An important property of monitoring through ocean color remote sensing is the concentration of chlorophyll in the ocean (or in freshwater), an index of phytoplankton biomass (IOCCG, 2008). In aquatic systems, phytoplankton biomass is a key ecological property. Biological features produced by ocean phytoplankton are important for fisheries resources and marine aquaculture development. The production of ocean color data has been conducted by earth-orbiting spacecrafts for almost thirty years, since the launch of the Coastal Zone Color Scanner (CZCS) in 1978. Numerous authors have demonstrated the use- fulness of ocean color data for studying physical and biological processes in coastal, marine and terrestrial areas (Asanuma et al., 2003; Hendiarti et al., 2004; Radiarta \& Saitoh, 2008).

The Indonesian archipelago is located between two continents (Asia and Australia) and plays a unique role in the global climate system. The variation of climate system drives the monsoons over the region. The Asia-Australia monsoon system is characterized by two monsoon regimes, namely the southeast and northwest monsoon (Hendiarti et al., 2004; Susanto et al., 2006). The southeast monsoon occurs during the months of June to September. This monsoon is associated with easterlies from

\# Corresponding author. Research Center for Aquaculture. Jl. Ragunan 20, Pasar Minggu, Jakarta Selatan 12540, Indonesia. Tel.: +62 217815052

E-mail address: radiarta@yahoo.com 
Australia that carry warm and dry air over the region. On the other hand, the northwest monsoon develops in the months of November to March, which is associated with westerlies from Asian continent that carry warm and moist air to the region. April, May, and October are transition months. Chlorophyll- $a$ (chl-a) concentrations in Indonesian seas exhibit seasonal variability, due to the influence of Asia-Australia monsoon (Susanto et al., 2006). Chl--a concentrations is higher during the southeast monsoon compared to the northeast monsoon. Hendiarti et al. (2004) found that chl--a concentration in the southeast of Java Sea was higher due to spatial extent of upwelling events during the southeast monsoon. Meanwhile, in the northern Malacca Straits, increased of chl- $a$ concentration was found during northwest monsoon (Tan et al., 2006).

This study focused on the Gulf of Tomini (Figure 1). The Gulf of Tomini is a semi-closed gulf located at the north-east of Sulawesi Island, connecting with Maluku Sea and Pacific Ocean through the east of the gulf. It lies between $1^{\circ} 302$ South - $1^{\circ} 302$ North and $120^{\circ}$ $125^{\circ}$ East (Figure 1). The Togian Islands spread at the centre of the gulf. This gulf provides an important role for the development of fisheries and marine aquaculture. To support sustainable use of marine and coastal resources in the gulf, three provinces (North Sulawesi, Gorontalo, and Central Sulawesi) have agreed to make a collaborative management.
In the Gulf of Tomini, several studies have been conducted including environmental characteristics, fisheries resources and aquaculture development (Badan Riset Kelautan dan Perikanan, 2003; Radiarta et al., 2005). However, few studies have used satellite data to investigate the characteristic of chl- $a$ variability in this region. In this present study, satellite ocean color time series data from SeaWiFS were used to determine the spatial and temporal variability of chl- $a$ in the Gulf of Tomini. The influences of sea surface temperature (SST) and winds on the variability of chl-a were also examined.

\section{MATERIALS AND METHODS}

\section{SeaWiFS Chl- $a$ Imagery}

The SeaWiFS instrument was launched on August $1^{\text {st }}, 1997$ on board the OrbView-2 spacecraft, and became operational on September $18^{\text {th }}, 1997$. With SeaWiFS, data on optical properties of global ocean condition is collected daily from the satellite, from which surface chl- $a$ can be estimated (McClain et al., 1998). The primary data used in this study were chl- $a$ concentration derived from SeaWiFS. A total of 96 GACs (global area coverage) data with a spatial resolution of $10 \mathrm{~km}$ were obtained from NOAA Coastwatch (http:// coastwatch.pfeg.noaa.gov/index.html), and processed with the Ocean Color 4 version 4 (OC4v4) algorithm (O'Reilly et al., 1998). These

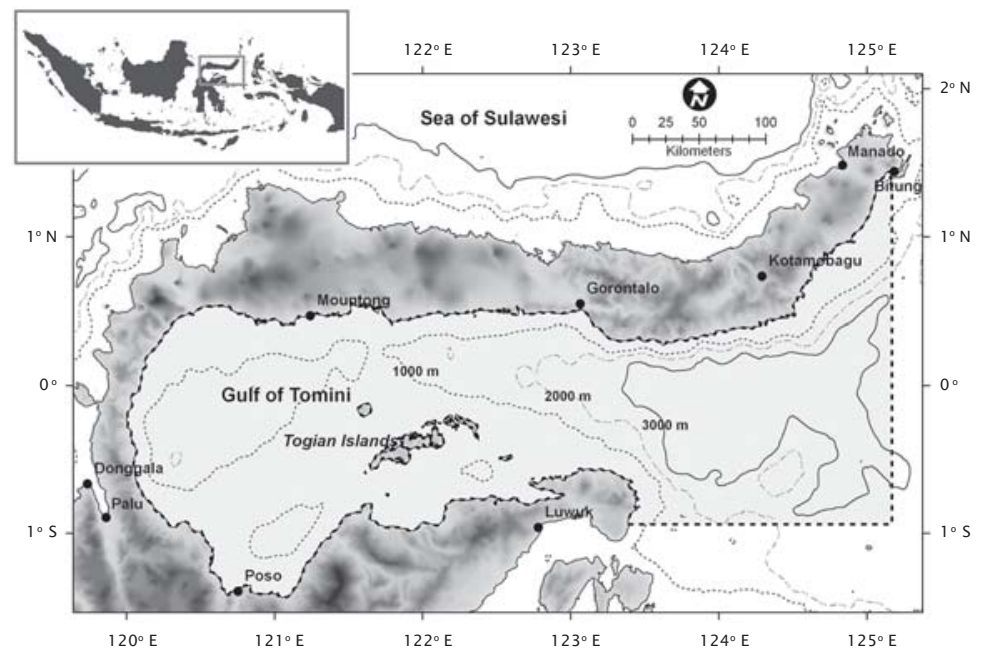

Figure 1. Map of the study area in the Gulf of Tomini and major depth contours (m). Polygon with dash line shows the SeaWiFS chl-a data sampling area 
files covered a time frame from January 2000 to December 2007. The accuracy of chlorophyll concentration estimations was about 30\% under ideal conditions. The monthly mean climatology was calculated from January 2000 to December 2007. The results were 12 monthly representations of climatological mean of chl-a variability.

To determine spatial pattern of chl- $a$ values, a sampling area was created around the gulf (polygon with dash line in Figure 1). Mean chl- $a$ values were calculated for every monthly images in the sampling area.

\section{Sea surface Temperature Imagery}

The principal dataset used for SST was obtained from the National Oceanic and Atmospheric Administration (NOAA) series of satellite. The NOAA satellites operate in a near polar sun-synchronous orbit at a height of about $850 \mathrm{~km}$ and provide a global coverage roughly twice daily. The latest version (version 5) of SST from the NOAA Advanced Very High Resolution Radiometer (AVHRR) oceans pathfinder data product was used in this study. The Pathfinder Version 5.0 SST data set is a reprocessing of global SST data from NOAA's AVHRR aboard NOAA's Polar Operational Environmental Satellites (POES) (Kilpatrick et al., 2001). Monthly composite SST GAC data with $4 \mathrm{~km}$ resolution were obtained from the NOAA-National Oceanographic Data Center (NODC, available at: http://www.nodc.noaa.gov/sog/ pathfinder $4 \mathrm{~km} /$ ). A total of 96 images were collected from January 2000 to December 2007. To be consistent with the temporal availability of the SeaWiFS data, the monthly climatological means were calculated on the basis of monthly means for eight years (2000-2007) of SST data.

\section{Wind Data}

The wind data used in this study were taken from NOAA-National Climatic Data Center (NCDC, available at: http:// www.ncdc.noaa.gov/oa/rsad/seawinds.html). These data contain globally gridded with the spatial resolution of $0.25^{\circ} \times 0.25^{\circ}$ (longitude $x$ latitude) (Zhang et al., 2006). Monthly wind speed data were collected from January 2000 to December 2007. To be consistent with the temporal availability of the SeaWiFS data, the monthly climatological means were calculated on the basis of monthly means for eight years (2000-2007) of wind data.

\section{Bathymetry}

Bathymetry data was also used in this study as supporting data. This data was extracted from the General Bathymetry Charts of the Ocean (GEBCO, available at: http:// www.gebco.net/). The bathymetry grid has a 30 arc second spatial resolution.

\section{RESULTS}

Seasonal variability of chlorophyll-a concentration and SST

Figure 2a presents patterns of climatological annual cycle of chl- $a$ concentration in the Gulf of Tomini as a monthly series. The analysis of monthly composite SeaWiFS chl-a images from 2000 to 2007 showed seasonal variability. Chl- $a$ concentrations were higher during the southeast monsoon in August than the northwest monsoon in November. A constantly high chl- $a$ concentration can only be observed along the eastern part of the gulf (on the mouth of the gulf). Chl- $a$ concentrations in the mouth of the gulf were significantly increasing starting from January, and in August the highest concentrations were observed. The concentration again decreased during the northwest monsoon (November).

Concurrent with the bloom was the occurrence of relatively cooler temperature in areas with high chl- $a$ concentration (Figure $2 b$ ). At the same time, a distinctively high SST inside the gulf could also be observed that associated with low chl-a concentrations (see Figure 2 May and November images). This is contrast with the low chl-- $a$ concentrations months when there is an almost uniform distribution of high SST.

The seasonal cycle of chl- $a$ concentration is shown in Figure 3a. The chl-a concentration peaked in August at every year from 2000 to 2007 , with the highest concentration $(0.43 \mathrm{mg}$ $\mathrm{m}^{-3}$ ) occurred in August 2004 and the lowest $\left(0.22 \mathrm{mg} \mathrm{m}^{-3}\right)$ in August 2000 . Chl- $a$ concentrations were observed low in November at every year $\left(<0.2 \mathrm{mg} \mathrm{m}^{-3}\right)$. An inverse relationship was observed between SST and chl- $a$ concentrations (Figure 3a, b). The lowest SST values occurred in August at every year and coincided with high chl- $a$ concentrations. From May, temperature began to decrease, reaching the minimum $\left(<29^{\circ} \mathrm{C}\right)$ in August. Increasing of SST value was observed two times a year with high increase $\left(>30^{\circ} \mathrm{C}\right)$ occurred in November every year. 


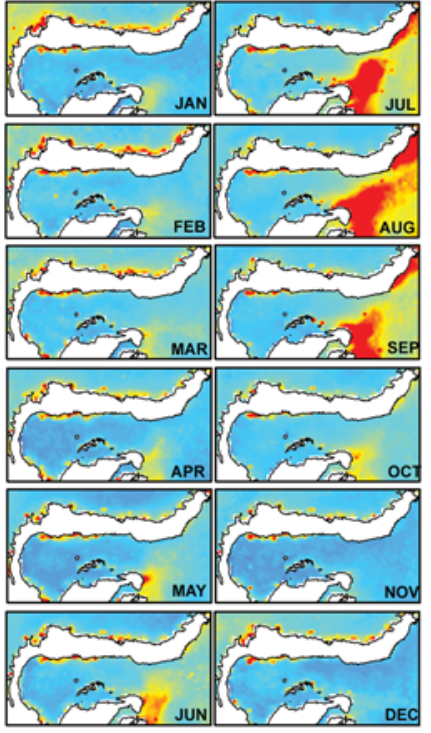

(a) SeaWiFs Chl-a ( $\left.\mathrm{mg} \mathrm{m}^{-3}\right)$ Low: 0.01 High: 0.5

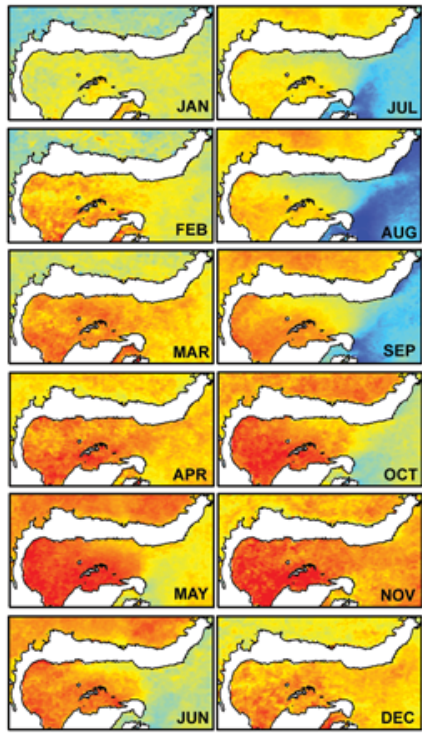

(b) Sea surface temperature $\left({ }^{\circ} \mathrm{C}\right)$ High: 30.5

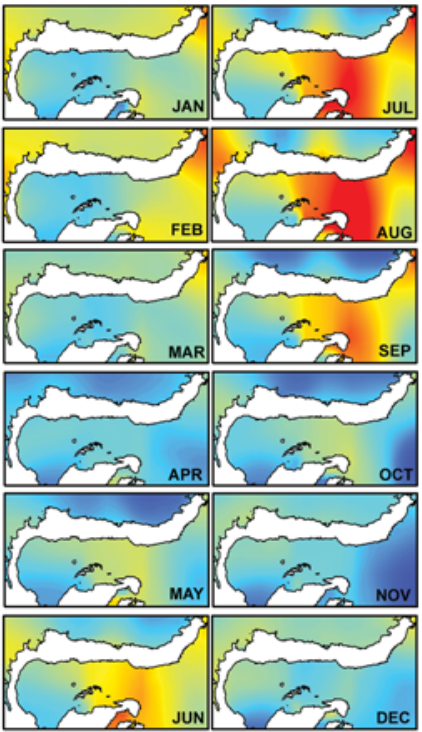

(c) Wind speed $\left(\mathrm{m} \mathrm{s}^{-1}\right)$

High: 7

Figure 2. Climatological monthly composite of SeaWiFS chl- $a$ images (a, $\mathrm{mg} \mathrm{m}^{-3}$ ), AVHRR pathfinder v. 5 SST $\left(b,{ }^{\circ} \mathrm{C}\right)$ and wind speed $\left(\mathrm{c}, \mathrm{m} \mathrm{s}^{-1}\right)$ from January 2000 to December 2007. Land and no data are presented in white. Coastline is presented in black

\section{The influence of wind}

To describe the air-sea interaction in the study area, sea surface wind speed data were also analyzed from January 2000 to December 2007. Monthly average wind speed revealed a seasonal cycle (Figures 2c and 3c). Wind speeds were highest every year during the southeast monsoon in August, with the highest wind speed occurred in August 2006 (6.41 $\left.\mathrm{m} \mathrm{s}^{-1}\right)$. The lowest wind speeds occurred in November, with the lowest wind speeds occurred in November 2004. Generally, the timing of the highest wind speed was coincided with the highest chl- $a$ concentration (Figure $3 a$ and $c)$.

\section{DISCUSSION}

Satellite Ocean color data were used intensively in this study to investigate the spatial and temporal variability of chlorophyll concentrations in the Gulf of Tomini. Each year the highest chl--a concentrations occurred during the southeast monsoon in August (Figure $2 \mathrm{a}$ ), while the low concentrations were observed during the northwest monsoon. This occurrence is consistent with the findings of previous researches (i.e., Hendiarti et al., 2004;
Susanto et al., 2006). During the southeast monsoon (June-September), because of strong wind and surface water cooling (Figure 2), convectional mixing of water column develops, which introduces nutrients up to the sea surface. A high nutrient supply to the surface during this time is presumably one of the factors supporting an increase of chl- $a$ concentrations in this region, particularly along the eastern part of the gulf. This indicates that wind condition and surface heating may contribute to the variation of chl- $a$ concentrations. Through statistical analysis, the influences among parameters were indicated highly significant (Table 1). Significant correlations were found between monthly composite chl- $a$ concentration and wind speed $(0.79,99 \%$ significant level; Table 1), suggesting that winds contributed to the variability of chl- $a$ concentrations through vertical mixing. A significant negative correlation occurred between monthly mean SST and chl- $a$ concentrations ($0.76,99 \%$ significant level; Table 1) and SST and wind speed $(-0.75,99 \%$ significant level; Table 1).

Satellite can be used to characterize the habitat and ecosystem properties that influ- 


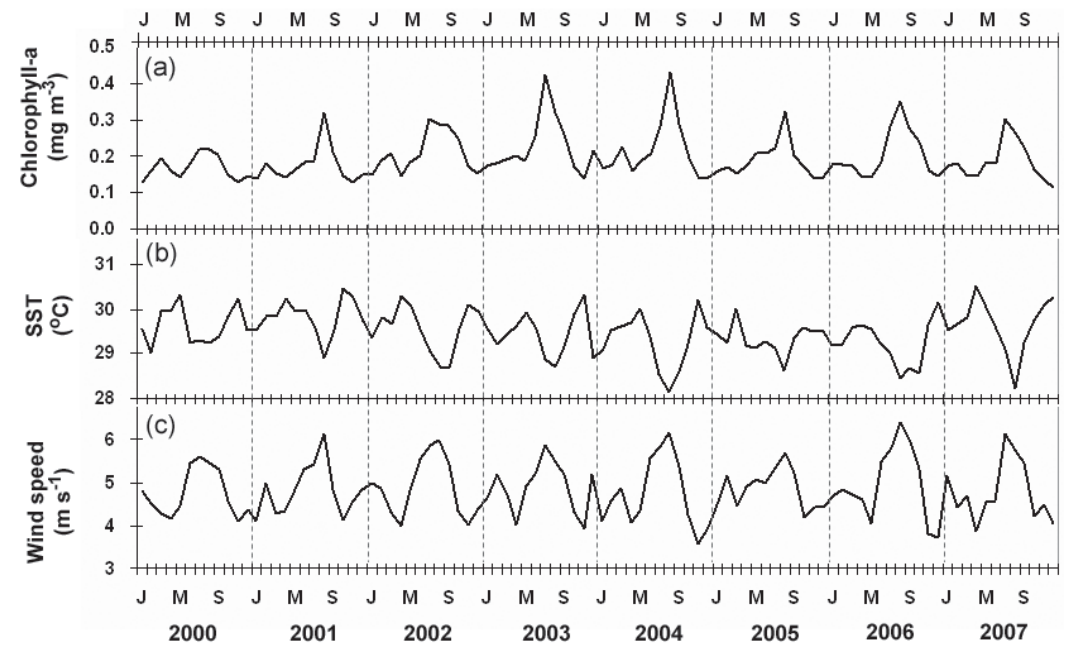

Figure 3. Time series of (a) SeaWiFS chl-a concentration $\left(\mathrm{mg} \mathrm{m}^{-3}\right)$, (b) sea surface temperature $\left({ }^{\circ} \mathrm{C}\right)$ and wind speed $\left(\mathrm{m} \mathrm{s}^{-1}\right)$ on monthly basis. SeaWiFS chl- $a$ and sea surface temperature are sampled from the polygon with dash line around the gulf (Figure 1)

ence marine resources at large (or high) temporal and spatial scale (or resolution) (IOCCG 2008). In terms of aquaculture development, ocean color data can be used to monitor a number of environmental issues that impact aquaculture activities, such as harmful algal blooms (Wang et al., 2008) and coastal pollution (Hendiarti et al., 2004; Yan \& Tang, 2009). In addition, ocean color data are also used in planning and management of marine aquaculture (Kapetsky \& Anguilar-Manjarrez, 2007), such as identification of suitable sites for expansion (Pérez et al., 2005; Radiarta et al., 2008). In aquaculture development, the use of oceancolor products can potentially meet the operational and conservation monitoring needs cost-effectively, with spatial and temporal coverage unachievable by other methods.

\section{CONCLUSION}

This study demonstrates the usefulness of satellite ocean color data in determining the synoptic quantifications of spatial and temporal variability of chl- $a$ concentration in the Gulf of Tomini. High chl-- $a$ concentrations were observed in August at every year from 2000 to 2007 , followed by low chl- $a$ concentration in November. The use of satellite data has made it possible to get several complete views of high chlorophyll regions and its presence and absence during various months of the corresponding year. However, a better understanding of biological and oceanographic process could be achieved through combining satellite remote sensing data and concurrent field survey measurements.

Table 1. Correlation coefficients (Pearson correlation) between environmental parameters and wind speed

\begin{tabular}{lccc}
\hline & Chlorophyll-a & $\begin{array}{c}\text { Sea surface } \\
\text { temperat ure }\end{array}$ & $\begin{array}{c}\text { Wind } \\
\text { speed }\end{array}$ \\
\hline Chlorophyll-a & 1 & $-0.76^{* *+}$ & $0.79^{* * *}$ \\
Sea surface & 1 & $-0.75^{* * *}$ \\
temperature & & 1 \\
Wind speed & & & 1 \\
\hline
\end{tabular}

Significant at $99 \%$ confident level 


\section{ACKNOWLEDGEMENTS}

The author thanks to NOAA CoastWatch, National Oceanographic Data Center (NODC) and National Climatic Data Center (NCDC) for providing the SeaWiFS chl-a, sea surface temperature and wind data, respectively.

\section{REFERENCES}

Asanuma, I., Matsumoto, K., Okano, H., Kawano, T., Hendiarti, N.,\& choemar, S.I., 2003. Spatial distribution of phytoplankton along the Sunda Islands: The monsoon anomaly in 1998. Journal of Geophysical Research. 108 (C6), 3202, doi:10.1029/1999JC000139.

Badan Riset Kelautan dan Perikanan.2003. Profil Sumberdaya Kelautan dan Perikanan Teluk Tomini. Burhanuddin et al. (eds.). BRKP, Departemen Keluatan dan Perikanan. 84 pp.

Hendiarti, N., Siegel, H., \& Ohde, T. 2004. Investigation of different coastal processes in Indonesian waters using Sea-WiFS data. Deep Sea Research Part II, 51: 85-97.

IOCCG. 2008. Why ocean colour? The social benefits of ocean-colour technology. Platt, T., Hoepffner, N., Stuart, V., \& Brown, C. (eds.), Report of the international oceancolour coordinating group, No. 7, IOCCG, Dartmouth, Canada. 141 pp.

Kapetsky, J.M. \& Anguilar-Manjarrez, J. 2007. Geographic information systems, remote sensing and mapping for the development and management of marine aquaculture. FAO Fish. Tech. Pap. No. 458. Rome, 125 pp.

Kilpatrick, K.A., Podesta, G.P., \& Evans, R. 2001. Overview of the NOAA/NASA Advanced Very High Resolution Radiometer Pathfinder algorithm for sea surface temperature and associated matchup database, Journal of Geophysical Research-Oceans. 106(C5): 9179-9197.

McClain, C.R., Cleave, M.L., Feldman, G.C., Gregg, W.W., Hooker, S.B., \& Kuring, N. 1998. Science quality seaWiFS data for global biosphere research. Sea Technology, 39: 1016.

O’Reilly, J.E., Moritorena, S., Mitchell, B.G., Siegel, D.A., Carder, K.L., Garver, S.A., Kuhru, M., \& McClain, C. 1998. Ocean color chlorophyll algorithms for SeaWiFS. Journal of Geophysical Research, 103: 24937-24953.
Pérez, O.M., Telfer, T.C., \& Ross, L.G.. 2005. Geographical information system-based models for offshore floating marine fish cage aquaculture site selection in Tenerife, Canary Islands. Aquaculture Research, 36: 946-961.

Radiarta, I.N. \& Saitoh, S-I., 2008. Satelite-derived measurements of spatial and temporal chlorophyl-a variability in Funka Bay, southwestern Hokkaido, Japan. Estuarine, Coastal and Shelf Science, 79: 400-408.

Radiarta, I.N., Saitoh, S-I., \& Miyazono, A. 2008. GIS-based multi-criteria evaluation models for identifying suitable sites for Japanese scallop (Mizuhopecten yessoensis) aquaculture in Funka Bay, southwestern Hokkaido, Japan. Aquaculture. 284: 127135.

Radiarta, I.N., Saputra, A., \& Johan, O. 2005. Area suitability mapping for mariculture development using application remote sensing data and geographic information system in Lemito coastal area, Gorontalo Province. Jurnal Penelitian Perikanan Indonesia, 1: 1-14. (In Indonesian with English abstract)

Susanto, R.D., Moore II, T.S., \& Marra, J. 2006. Ocean color variability in the Indonesian Seas during the SeaWiFS era. Geochemistry Geophysics Geosystems. 7, Q05021, doi:10.1029/2005GC001009.

Tan, C.K, Ishizaka, J., Matsumura, S., Yusoff, F.Md., \& Mohamed, M.I.Hj. 2006. Seasonal variability of SeaWiFS chlorophyll a in the Malacca Strait in relation to Asian monsoon. Continental Shelf Research, 26: 168-178.

Wang, S., Tang, D., He, F., Fukuyo, Y., \& Azanza, R.V. 2008. Occurrences of harmful algal blooms (HABs) associated with ocean environment in the South China Sea. Hydrobiologia, 596: 79-93.

Yan, Z. \& Tang, D. 2009. Changes in suspended sediments associated with 2004 Indian Ocean tsunami. Advances in Space Research, 43: 89-95.

Zhang, H.-M., Reynolds, R.W., \& Bates, J.J. 2006. Blended and Gridded High Resolution Global Sea Surface Wind Speed and Climatology from Multiple Satellites: 1987 - Present. American Meteorological Society 2006 Annual Meeting, Paper \#P2.23, Atlanta, GA, January 29 - February 2, 2006. 